\title{
Analisis Sistem Informasi Union Catalogue Perpustakaan UIN Raden Fatah Palembang dengan Pendekatan EUCS
}

\author{
Rusmiatiningsih \\ UIN Raden Fatah Palembang, Palembang Indonesia \\ rusmiatiningsih_uin@ radenfatah.ac.id
}

\begin{abstract}
The Library of UIN Raden Fatah Palembang is one of the university libraries that uses a system automation and union catalog system to meet the information needs of the academic community. This study aims to determine the level of satisfaction of users in utilizing union catalog using the End User Computing Catalog Satisfaction (EUCS) approach. This study uses a quantitative method with a total sample of 100 visitors to the Palembang Raden Fatah UIN Library. From the calculation of the mean and grand mean it was found that the subvariable content obtained a high score of 3.98, the subvariable accuracy obtained a high score of 3.97. In the subvariabel the format obtained a high score of 4.09. punctuality earned a high score of 4.01. The grand mean catalog satisfaction variable together with the End User Computing Satisfaction approach, obtained a value of 4.03 from the average value of 5 satisfaction subvariables. With a value of 4.01 which indicates that user satisfaction is at a high level.
\end{abstract}

Keywords: author guidelines, Pustaka Budaya, article template

1.

\section{Pendahuluan}

Penerapan teknologi informasi dan komunikasi di berbagai bidang tugas, pekerjaan dan layanan publik merupakan hal wajib. Terutama dalam bidang perpustakaan, teknolog informasi dirasa menjadi kewajiban yang harus diterapkan di segala lini layanan. Perpustakaan sebagai salah satu layanan publik secara umum maupun khusus juga mau tidak mau menerapkan teknologi informasi dan komunikasi dalam setiap lini layanannya.

Penerapan teknologi di perpustakaan diawali dengan penggunaan perangkat lunak dan perangkat keras, yang kemudian disebut sebagai otomasi perpustakaan. Otomasi perpustakaan merupakan kombinasi antara perangkat keras dan perangkat lunak. Perangkat keras berupa hardware meliputi perlengkapan komputer yang terhubung dengan internet, sedangkan perangkat lunak adalah software berupa aplikasi khusus untuk menjalankan otomasi mengelola sumber informasi perpustakaan. (Suprianto, 2008: 49).

Salah satu software otomasi open source yang banyak digunakan adalah software manajemen perpustakaan SLIMS (Senayan Library Management 
System). Selain sebagai sistem otomasi SLIMS juga mempunyai kelebihan yaitu bisa digunakan sebagai sebagai katalog bersama atau union katalog.

Saat ini perpustakaan UIN Raden Fatah melayani 9 Fakultas dan 1 sekolah Pascasarjana, Untuk memudahkan penelusuran informasi Perpustakaan UIN raden fatah memiliki portal katalog induk, dengan adanya layanan tersebut, dihatrapkan mampu memenuhi kebutuhan pengguna dalam mengakses informasi bahan pustaka.

Semua peningkatan layanan perpustakaan yang telah ditawarkan oleh Perpustakaan UIN Raden Fatah tersebut seharusnya bisa dimanfaatkan dan memberikan kepuasan bagi pengguna perpustakaan. Oleh karena itu, penelitian ini bertujuan untuk menggali informasi sejauh mana katalog bersama/union catalogue dimanfaatkan dan telah memberikan kepuasan bagi pemustakanya.

Kemudian, untuk mengukur tingkat kepuasan pemustaka dalam memanfaatkan union catalog tersebut digunakan sebuah pendekatan end user computing satisfaction (EUCS).

\section{Metode}

Penelitian ini termasuk jenis penelitian deskriptif kuantitatif. Polulasi dalam penelitian ini adalah jumlah pengunjung perpustakaan pada tahun 2017 yaitu sebanyak 31025 pengunjung. Penentuan sampel menggunakan rumus solovin dengan tingkat kesalahan sebesar $10 \%$

$$
\begin{aligned}
& n=\frac{N}{1+\mathrm{Ne}^{2}} \\
& n=\frac{31025}{1+31025 \times 00,1^{2}} \\
& n=99,75 \\
& \mathrm{n}=\text { jumlahsampel } \\
& \mathrm{N}=\text { jumlah seluruh anggota populasi } \\
& \mathrm{e}=\text { toleransi terjadinya galat; taraf signifikansi) }
\end{aligned}
$$

99,75 dibulatkan menjadi 100 sampel.

Teknik analisis data menggunakan rumus mean dan grand mean.

rumus mean digunakan untuk mengetahui nilai rata-rata dari setiap butir instrumen.

\footnotetext{
Mean $\mathrm{x}=\left(\sum \mathrm{X}\right) / \mathrm{N}$ Keterangan:

$\mathrm{X}$ : rata-rata hitung / mean

$\sum \mathrm{X} \quad$ : jumlah semua nilai kuesioner

$\mathrm{N} \quad$ : jumlah responden

Setelah diketahui rata-rata dari jawaban responden, lalu dilakukan perhitungan menggunakan rumus grand mean untuk mengetahui rata-rata umum dari masing-masing butir pernyataan. rumus grand mean adalah sebagai berikut:
}

$$
\operatorname{GrandMean}(\mathrm{X})=\frac{\text { Total rata }- \text { rata hitung }}{\text { Jumlah pernyataan }}
$$


Untuk penafsiran mean dan grand mean menggunakan sekala dibawah ini.

$$
\begin{aligned}
& 4,20-5,00=\text { Sangat Tinggi } \\
& 3,40-4,20=\text { Tinggi } \\
& 2,60-3,40=\text { Sedang } \\
& 1,80-2,60=\text { Rendah } \\
& 1,00-1,80=\text { Sangat Rendah }
\end{aligned}
$$

\section{Hasil Dan Pembahasan \\ 4.1 Variabel Kepuasan Pengguna \\ 4.1.1 Subvariabel Isi (content)}

Dari analisis menggunakan rumus mean dan grand mean dari 6 indikator subvariabel isi diketahui subvariabel isi (content) katalog mempunyai nilai grand mean rata-rata 3,82. Nilai tertinggi pada indikator memberikan informasi sesuai dengan kata kunci. Sedangkan nilai terendah pada indikator isi yang dihasilkan sistem katalog bersama telah memenuhi kebutuhan.

B. Subvariabel Keakuratan (Accuracy)

Dari analisis menggunakan rumus mean dan grand mean dari menunjukkan bahwa 5 indikator untuk subvariabel Keakuratan (Accuracy) diperoleh nilai grand mean rata-rata 3,92 dengan kategori tinggi. Nilai tertinggi terlihat oleh indikator informasi yang tersedia di katalog bersama bermanfaat bagi Anda. Sedangkan nilai terendah indikator terlihat pada indikator Katalog bersama memberikan informasi yang akurat sesuai kata kunci dan informasi yang ditampilkan di katalog bersama tidak mengalami kesalahan penulisan.

C. Subvariabel bentuk (format)

Dari analisis menggunakan rumus mean dan grand mean dari menunjukkan bahwa 8 indikator untuk subvariabel bentuk (format) diperoleh nilai rata-rata 4,0 dengan kategori tinggi. Nilai tertinggi terlihat oleh indikator Warna tampilan katalog bersama konsisten dan nyaman untuk dibaca, Ukuran teks katalog bersama mudah dibaca dan tidak terlalu kecil, Informasi pada katalog. Sedangkan nilai terendah indikator terlihat pada indikator system navigasi catalog Bersama ,mudah dipahami pengguna.

D. Subvariabel Kemudahan (Ease of Use)

Dari analisis menggunakan rumus mean dan grand mean dari 6 indikator untuk subvariabel kemudahan (ease of use) diperoleh nilai rata-rata 4,13 dengan kategori tinggi.

Nilai tertinggi terlihat oleh indikator Katalog Bersama mudah digunakan, sedangkan nilai terendah indikator terlihat pada indikator Halaman katalog Bersama mudah dipahami pengguna, Katalog Bersama mudah dipelajari, Pengguna dapat memasukan kata kunci di system navigasi dengan mudah, Proses menelusur informasi katalog Bersama dapat dilakukan dengan mudah, Katalog Bersama dapat diakses secara online di dalam dan luar kampus dengan mudah. E. Subvariabel ketepatan waktu (timeline) 
Untuk mengetahui tingkat subvariabel ketepatan waktu (timeline) maka selanjutnya dilakukan perhitungan menggunakan grand mean, setelah sebelumnya diketahui nilai mean dari 4 butir pernyataan kuesioner. Nilai grand mean akan disajikan dalam bentuk tabel, yaitu dengan cara mengelompokkan masing-masing pernyataan ke dalam kelompok indikator. Dari hasil perhitungan grand mean dari 4 indikator untuk subvariabel ketepatan waktu (timeline) diperoleh nilai rata-rata 3,9 dengan kategori tinggi.

Nilai tertinggi terlihat oleh Katalog Bersama memunculkan informasi yang anda cari dengan cepat (on click acces), sedangkan nilai terendah indikator terlihat pada Katalog Bersama dapat dikases dengan cepat tanpa mengalami lambat koneksi internet, Katalog bersama menampilkan update buku baru.

2. Analisis Kepuasan pada Katalog Bersama menggunakan pendekatan EUCS

Untuk mengetahui tingkat kepuasan pengguna katalog bersama dengan pendekatan end user computing satisfation, maka selanjutnya dilakukan perhitungan menggunakan grand mean, setelah sebelumnya diketahui nilai mean dari 4 subvariabel.

Nilai grand mean akan disajikan dalam bentuk tabel, yaitu dengan cara mengelompokkan masing-masing pernyataan ke dalam kelompok subvariabel. Di bawah ini adalah hasil analisis deskriptif menggunakan rumus mean dan grand mean dari subvariabel dan variabel kepuasan pengguna katalog bersama dengan pendekatan end user computing satisfation. menunjukkan bahwa 5 subvariabel mendapatkan nilai rata-rata 4,03 dengan kategori tinggi. Nilai tertinggi terlihat oleh subvariabel kemudahan, sedangkan nilai terendah subvariabel keakuratan.

\section{Simpulan}

Berdasarkan hasil analisis data dari penelitian yang berjudul "Analisis Sistem Informasi Katalog Bersama Pepustakaan UIN Raden Fatah Palembang dengan Menggunakan Pendekatan End User Computing Satisfaction (EUCS)" maka dalam penelitian ini bisa disimpulkan beberapa hal, yaitu:

1). Konten

Subvariabel Konten memperoleh nilai grand mean 3,98. Nilai tersebut berada pada rentang skala 3,40 - 4,20 yang menunjukkan bahwa konten katalog bersama berada pada tingkat yang tinggi. Skor tertinggi terdapat pada indikator Kesesuaian kebutuhan pengguna, khusunya pernyataan "memberikan informasi sesuai dengan kata kunci" yang memperoleh skor 4,2 (sangat tinggi). Sedangkan yang mendapatkan skor terendah terdapat pada indikator Isi sesuai modul terutama pada pernyataan "Isi yang dihasilkan system katalog Bersama telah memenuhi kebutuhan Anda" yang memperoleh skor 3,7 (tinggi).

\section{2). Keakuratan (Accuracy)}

Subvariabel Hasil Output memperoleh nilai grand mean 3,92. Nilai tersebut berada pada rentang skala 3,40 - 4,20 yang menunjukkan bahwa hasil output katalog bersama berada pada tingkat yang tinggi. Skor tertinggi terdapat pada indikator "Informasi yang tersedia di katalog

bersama bermanfaat bagi Anda" memperoleh skor 4,1 (tinggi). Sedangkan yang mendapatkan skor terendah terdapat pada indikator Informasi yang 
ditampilkan di katalog bersama tidak mengalami kesalahan penulisan yang memperoleh skor 3,8 (tinggi).

3). Bentuk (format)

Subvariabel bentuk (format) memperoleh nilai grand mean 4.09. Nilai tersebut berada pada rentang skala 3,40 - 4,20 yang menunjukkan bahwa format katalog bersama berada pada tingkat yang tinggi. Skor tertinggi terdapat pada indikator "Informasi pada katalog Bersama mudah dibaca" memperoleh skor 4,19 (tinggi). Sedangkan yang mendapatkan skor terendah terdapat pada indikator "system navigasi catalog Bersama, mudah dipahami pengguna" yang memperoleh skor 3,91 (tinggi).

4). Kemudahan (ease of use)

Subvariabel Kemudahan (ease of use) memperoleh nilai grand mean 4.13. Nilai tersebut berada pada rentang skala 3,40 - 4,20 yang menunjukkan bahwa format katalog bersama berada pada tingkat yang tinggi. Skor tertinggi terdapat pada indikator "Proses menelusur informasi katalog Bersama dapat dilakukan dengan mudah" memperoleh skor 4,14 (tinggi). Sedangkan yang mendapatkan skor terendah terdapat pada indikator "Katalog Bersama dapat diakses secara online di dalam dan luar kampus dengan mudah" yang memperoleh skor 4,10 (tinggi).

\section{5). Subvariabel ketepatan waktu (timeline)}

Subvariabel Subvariabel ketepatan waktu (timeline) memperoleh nilai grand mean 4.01. Nilai tersebut berada pada rentang skala 3,40 -

4,20 yang menunjukkan bahwa ketepatan waktu katalog bersama berada pada tingkat yang tinggi. Skor tertinggi terdapat pada indikator "Katalog Bersama memunculkan informasi yang anda cari dengan cepat (on click acces)" memperoleh skor 4,14 (tinggi). Sedangkan yang mendapatkan skor terendah terdapat pada indikator "Katalog Bersama dapat dikases dengan cepat tanpa mengalami lambat koneksi internet" yang memperoleh skor 3,91 (tinggi).

Kepuasan Pengguna Katalog Bersama dengan End User Computing Satisfation memperoleh nilai grand mean 4,03 dari nilai rata-rata 5 subvariabel kepuasan, nilai tersebut terdapat dalam rentang Subvariabel ketepatan waktu (timeline) memperoleh nilai grand mean 4.01. Nilai tersebut berada pada rentang skala 3,40 - 4,20 yang menunjukkan bahwa Kepuasan Pengguna Katalog Bersama dengan End User Computing Satisfation berada pada tingkat yang tinggi.

Berdasarkan kesimpulan di atas, ada beberapa saran yang peneliti kemukakan terkait Analisis Sistem Informasi Katalog Bersama Pepustakaan UIN Raden Fatah Palembang dengan Menggunakan Pendekatan End User Computing Satisfaction (EUCS), yaitu:

1. Perlunya pustakawan meningkatkan keahlian (skill) terutama dalam standarisasi input koleksi bibliografi kedalam katalog bersama. Hal ini terlihat di beberapa pernyataan yang mempunyai grand mean rendah seperti isi yang dihasilkan katalog bersama telah memenuhi kebutuhan Anda. Informasi yang ditampilkan tidak mengalami kesalahan penulisan. 
2. Perlunya membuat navigasi katalog yang memudahkan pengguna dalam mengakses informasi katalog bersama Hal ini terlihat di beberapa pernyataan yang mempunyai grand mean rendah seperti sistem navigasi katalog bersama mudah dipahami pengguna

\section{Daftar Pustaka}

Azleen Iliasa, Mohd Rushdan Yasoa'a, Mohd Zulkeflee Abd Razaka Rahida AbdulRahmana. The Study Of End-User Computing Satisfaction (Eucs) On Computerised Accounting System (Cas) Among Labuan F.T. Government Sectors: A Case Study In The Responsibility Centres . Labuan e-Journal of Muamalat and Society, Vol. 1, 2007, pp. 1-13

Fifi Cahaya K. Karakteristik Pengguna Yang Memanfaatkan Perpustakaan Umum Kota Surabaya (Study Deskriptif Tentang Karakteristik Pengguna Yang Memanfaatkan Perpustakaan Umum Kota Surabaya): Jurnal Unair, 2012. (Http://Journal.Unair.Ac.Id/Download-Fullpapers-

Jurnal\%20karakteristik\%20pengguna\%20yang\%20memanfaatkan\%20p erpustakaan\%20umum\%20kota\%20surabaya.Pdf)

Muhammad Ngafii, Kemajuan Teknologi Dan Pola Hidup Manusia Dalam Perspektif Sosial Budaya, Jurnal Pembangunan Pendidikan: Fondasi Dan Aplikasi, Vol.2 No.1, 2014.

Nurmaini Dalimunthe, Cici Ismiati. Analisis Tingkat Kepuasan Pengguna Online Public Acces Catalog (OPAC) dengan Metode EUCS (Studi Kasus: Perpustakaan UIN SUSKA Riau). Jurnal Rekayasa dan Manajemen Sistem Informasi, Vol.2, No.1, Februari 2016.

Sugiyono, Metodepenelitianpendiidkanpendekatankuantitatif, Kulalitatif Dan R\&D (Bandung: Alfabeta, 2013), 117

Cohn, J. M., Kelsey, A. L., \& Fiels, K. M. (2001). Planning For Integrated Systems And Technologies : A How-To-Do-It Manual For Librarians. Illionis: Neal-Schuman Publisher

Sugiyono, Metodepenelitiankuantitatifkualitatif Dan R\&D (Bandung: Alfabeta, 2010).

Jr Rico, Metodepenelitiankualitatif, (Jakarta: Pt Grasindo, 2010), 112.

Basuki, S. (1994). Periodesasi Perpustakaan Indonesia. Bandung: Remaja Rosda Karya.

Saleh, A. R. (2010). Membangun Perpustakaan Digital. Jakarta: Sagung Seto.

Muhammad Azwar, Membangun Sistem Otomasi Perpustakaan Dengan Senayan Library Management System (Slims), Khizanah Al-Hikmah Vol. 1 No.1, Januari - Juni 2013 